\title{
Pelaksanaan Program Kota Tanpa Kumuh Di Kota Padang
}

\author{
Musral Linggawati, Yusnanik Bakhtiar \\ Program Studi Pendidikan Pancasila dan Kewarganegaraan \\ Universitas Negeri Padang \\ E-mail: musrallinggawati@gmail.com
}

\begin{abstract}
ABSTRAK
Permukiman kumuh merupakan permasalahan yang sejak lama terjadi dan juga menjadi hambatan utama bagi perkembangan kota-kota besar, termasuk salah satunya Kota Padang tepat nya di Kelurahan Dadok Tunggul Hitam dan Kelurahan Alai Parak Kopi. Sejalan dengan permasalahan tersebut Kementrian Pekerjaan Umum dan Perumahan Rakyat Indonesia membuat suatu program strategi penanganan permukiman kumuh secara nasional yang bernama Program Kota Tanpa Kumuh (Kotaku). Program ini pelaksanaan nya di Kelurahan Dadok Tunggul Hitam dan Kelurahan Alai Parak Kopi. Penelitian ini bertujuan untuk mengatahui pelaksanaan program Kota Tanpa Kumuh, Partisipasi Masyarakat, dan Kendala selama pelaksanaan nya.Jenis penelitian yang digunakan adalah Field research dengan metode deskriptif melalui pendekatan kualitatif. Informan Penelitian ini adalah Aparatur Kecamatan, Kelurahan, Lembaga Pemberdayaan Masyarakat (LPM), Penggiat Program Kota Tanpa Kumuh dan elemen masyarakat. Teknik pengumpulan data melalui observasi, wawancara, dan dokumentasi. Hasil Penelitian ini menunjukan bahwa pelaksanaan program Kota Tanpa Kumuh di Dua Kelurahan tersebut sudah berjalan dengan baik, serta partisipasi masyarakat nya yang siginifikan, serta kendala yang dihadapi juga tidak begitu banyak, hanya saja sebagian masyarakat belum memahami akan adanya tujuan program Kota Tanpa Kumuh tersebut dikarenakan ada kesibukan pekerjaan.
\end{abstract}

\section{Kata Kunci : Program Kota Tanpa Kumuh, Partisipasi Masyarakat}

\section{ABSTRACT}

Slum is a problem that has long since occurred and also become the main obstacle to the development of large cities, including one of Padang's right city in the village of Dadok Tunggul Hitam and village of Alai Parak Kopi. In line with the problem, the Ministry of Public Works and housing of the Indonesian people created a national slum handling strategy program called the Program Kota Tanpa Kumuh (Kotaku). This Program is in the implementation of Dadok Tunggul Hitam and Alai Parak Kopi. This research aims to meet the implementation of the Ungrungy City program, community participation, and constraints during its implementation. The type of research used is Field research with a descriptive method through a qualitative approach. The informant of this research is a subdistrict apparatus, Kelurahan, Community Empowerment Institute (LPM), an ungrungy city Program activists and elements of society. Data collection techniques through observation, interviews, and documentation. The results of this research show that the implementation of the Ungrungy City program in the two villages is already running well, as well as the participation of its significant community, as well as the constraints are also 
not so much, only partly People do not understand the purpose of the program of the Ungrungy city because there is busy work.

Keywords : Program Kota Tanpa Kumuh, Partisipasi Masyarakat

\section{PENDAHULUAN}

Berdasarkan UU Nomor 1 Tahun 2011 tentang Perumahan dan Kawasan Permukiman dijelaskan bahwa permukiman kumuh adalah permukiman yang tidak layak huni karena ketidakteraturan bangunan, tingkat kepadatan bangunan yang tinggi, dan kualitas bangunan serta sarana dan prasarana yang tidak memenuhi syarat, sedangkan Perumahan Kumuh adalah perumahan yang mengalami penurunan kualitas fungsi sebagai tempat hunian. Menurut UndangUndang Dasar Tahun 1945 Pasal 48H Ayat 1 menyatakan bahwa Setiap orang berhak untuk hidup sejahtera lahir dan bathin, bertempat tinggal, dan mendapatkan lingkungan hidup yang baik dan sehat, serta berhak memperoleh pelayanan kesehatan. Pasal tersebut menunjukan bahwa tinggal di lingkungan yang layak huni merupakan hak dasar yang harus dijamin pemenuhannya oleh pemerintah sebagai penyelenggaraan suatu negara.

Berdasarkan penjelasan tersebut, dalam realitanya sesuai dengan pengamatan terhadap situasi dan kondisi di wilayah pemerintahan yang bisa dikatakan tidak layak huni menjadi satu permasalahan besar terhadap kelangsungan hidup masyarakat setetmpat yang berada di kawasan kumuh tersebut.Untuk menangani fenomena adanya permukiman kumuh,Direktorat Jendral Cipta Karya Kementrian Pekerjaan Umum dan Perumahan
Rakyat mengeluarkan Surat Edaran Nomor 40/SE/DC/2016 tentang Pedoman Umum Program Kota Tanpa Kumuh. Kota Tanpa Kumuh merupakan program yang bermaksud untuk penanganan permukiman kumuh, dimana Pemerintah Daerah memimpin dan berkolaborasi dengan para pemangku kepentingan dalam perencanaan maupun implementasi serta mengedepankan partisipasi dari masyarakat.

Tujuan program Kota Tanpa Kumuh yaitu meningkatkan akses terhadap infrastruktur dan pelayanan dasar di permukiman kumuh perkotaan untuk mendukung perwujudan permukiman perkotaan yang layak huni, produktif, dan berkelanjutan. Kota Padang yang menyandang status sebagai ibu kota Provinsi Sumatera Barat yang dihadapkan persoalan kumuh dengan luas wilayah $695 \mathrm{~km}^{2}$ dan kumuh sebesar 107,96 Ha terdiri dari 23 Kelurahan dari 104 Kelurahan yang mayoritas akibat padatnya permukiman serta tingkat ekonomi masyarakat rendah.Sebaran kawasan kumuh di Kota Padang terjadi pada lokasi-lokasi yang dekatdengan pusat perdagangan dan jasa serta pusat persawahan masyarakat setempat. Seperti beberapa Kelurahan yang ada di Kota Padang yaitu Kelurahan Dadok Tunggul tepatnya di RW 14 bisadikatakankelurahan yang tak layak untuk di huni, dimana setiap hujan datang masyarakat di kelurahan ini selalu saja terkena banjir, jalanan becek dan berlobang serta masih 
banyak lagi keluhan dari masyarakat setempat.

Satu lagi Kelurahan Alai Parak Kopi, kelurahan ini tidak lain permasalahannya dengan kelurahan dadok tunggul hitam, kelurahan ini juga termasuk kelurahan yang tak layak huni dimana jalanan di kelurahan ini masih belum di beri aspal, apabila hujan datang jalanannya menjadi becek. Dua Kelurahan ini merupakan beberapa kelurahan yang menjadi lokasisasaran KOTAKU yang sudah dilaksanakan sejak tahun 2017 danmenjadi salah satu prioritas peningkatankualitas permukiman kumuh tahappertama pada tahun 2017, dimanadikawasan Kelurahan Dadok Tunggul Hitam dan Kelurahan Alai Parak Kopi merupakan kawasan pusat bisnis dan heritage Kota Padang, dengan ada banyaknya pasar tradisional serta persawahan milik masyarakat sebagai salah satu penunjang pergerakan bisnis.

Dalam pelaksanaan program tentu saja sangat dibutuhkan keterlibatan masyarakat dalam pelaksanaan terutama masyarakat di Kelurahan Dadok dan Kelurahan Alai berdasarkan wawancara pra risetberkenaan dengan kegiatan pembangunan infrastruktur yang telah dibangun selaras dengan dana yang telah diterima dari pemerintah, tidak terlepas dari permasalahanpermasalahan yang timbul dalam pencapaian tujuan dari program tersebut di Kelurahan Dadok Tunggul Hitam dan Kelurahan Alai Parak Kopi, partisipasi masyarakat yang kurang dalam menghadiri rapat karena kesibukan masyarakat dalam hal pemenuhan kebutuhan mereka menjadikan mereka kadang sulit untuk mengambil keputusan mana yang harus di lakukan antara kepentingan individu atau kepentingan bersama. Kedua, Kurangnya pengetahuan dan pemahaman dari masyarakat mengenai maksud program yang di laksanakan di Kawasan lingkungan sekitar rumahnya, mereka beranggapan program ini adalah proyek besar yang di kira masyarakat LPM meminta jatah untuk melaksanakan program KOTAKU. Ketiga, adanya keterlambatan tugas kerja dalam proses pelaksanaan dilapangan yang berdampak pada segi waktu, bahan dan upah.

Berdasarkan

fenomenafenomena di atas, maka peneliti pun tertarik untuk melakukan penelitian lebih lanjut, yang dituangkan dalam sebuah karya ilmiah berbentuk skripsi dengan judul "Pelaksanaan Program Kota Tanpa Kumuh (KOTAKU) Studi Di Kelurahan Dadok Tunggul Hitam dan Kelurahan Alai Parak Kopi".

\section{METODE PENELITIAN}

Jenis penelitian ini yaitu penelitian Kualitatif dengan metode penelitian lapangan disebut juga dengan field research, yaitu penelitian yang dilakukan dalam kehidupan yang sebenarnya. Penelitian ini juga disebut dengan penelitian deskriptif, karena penelitian ini berfokus pada menggambarkan fenomena lapangan yang ditemui melalui hasil penelitian. Berdasarkan tujuan penelitian, permasalahan yang akan dikaji oleh peneliti merupakan masalah yang bersifat sosial dan dinamis (Sugiyono, 2014:60). Lokasi penelitian diambil berdasarkan data bahwa di kawasan Kelurahan Dadok Tunggul Hitam dan 
Kelurahan Alai Parak Kopi telah melaksanakan Program Kota Tanpa Kumuh. Oleh karena itu, lokasi tersebut menjadi objek penelitian peneliti. Informan penelitian adalah orang yang dimanfaatkan untuk memberikan informasi tentang situasi dan kondisi latar belakang penelitian. Pihak yang terlibat dalam penelitian ini yaitu pihak Program Kota Tanpa Kumuh di Kota Padang yaitu Bapak M. Bajang Armadi selaku Tim Leader Kotaku Wilayah II Sumbar, Bapak Ardi S selaku Kasi Kesejahteraan Sosial Kec. Koto Tangah, Bapak Rizki Nur Zaidhan, S.STP selaku Kasi Pemberdayaan Masyarakat Kec. Padang Utara, Ibuk Novita selaku Kasi Pemberdayaan Kesos Kel. Dadok Tunggul Hitam, Bapak Armen Sisnedi S. Ag selaku Koor LKM Saiyo Sakato Kel. Dadok Tunggul Hitam, Bapak Drs. Agustinus. SM., MM selaku Lurah Alai Parak Kopi, Ibuk Ratnawati selaku Koordinator Kasi Pemberdayaan Masyarakat dan Kesejahteraan Sosial Kel. Alai Parak Kopi, Ibuk Dewi selaku Bendahara KSM Kelurahan Alai Parak Kopi, Ibuk Siska selaku Masyarakat Dadok Tunggul Hitam, dan Ibu Dewi sasnita selaku Istri Ketua RT 01 RW 14 di Kelurahan Dadok Tunggul Hitam. Dapat dilakukan melalui observasi, wawancara, dokumentasi dan studi kepustakaan.

\section{HASIL DAN PEMBAHASAN}

1. Pelaksanaan Program Kota Tampa
Kumuh

Pelaksanaan program ini melalui beberapa tahap yaitu

a) Tahap persiapan dalam tahap ini meliputi dua kegiatan utama, yaitu: (1) sosialisasi dan membangun komitmen masyarakat yang dilakukan melalui berbagai kegiatan termasuk lokakarya orientasi tingkat Desa/Kel, (2) Pembentukan/Penguatan TIPP.

b) Kedua Tahap Perencanaan yaitu, dimulai dengan merumuskan kondisi permukiman layak huni ditingkat kelurahan atau antar kelurahan yang diinginkan oleh masyarakat pada masa mendatang, sesuai dengan visi dan misi pembangunan permukiman tingkat kelurahan untuk mencapai 0 ha permukiman kumuh yang dituangkan dalam Rencana Penataan Lingkungan Permukiman (RPLP) dengan kedalam rencana teknis. Dokumen RPLP Kumuh atau perencanaan yang setara, merupakan rencana makro Kelurahan yang memuat arahan pencegahan dan rencana peningkatan kualitas permukiman kumuh yang terintegrasi antar Kelurahan yang berbatasan. Perencanaan disajikan pada peta dengan skala ketelitian 1:5000 dan 1:1000.

c) Ketiga Tahap Pelaksanaan yaitu, Dalam tahapan pelaksanaan kegiatan baik kegiatan sosial, ekonomi maupun infrastruktur harus sesuai dengan perencanaan yang disusun dalam dokumen RPLP. Pelaksanaan semua kegiatan harus dilakukan dengan transparan dimana setiap transaksi harus dapat dipertanggungjawabkan dan dicatatkan dalam pembukuan. Tahapan pelaksanaan kegiatan dilaksanakan setelah dokumen RPLP disyahkan oleh pihak yang berwenang. Kegiatan yang 
dilaksanakan merupakan kegiatan yang tertera di RPLP serta merupakan kegiatan prioritas penanganan permukiman kumuh yang sudah ditetapkan sebelumnya

d) Tahap Keberlanjutan

Tahapan keberlanjutan diartikan sebagai tahap setelah pelaksaaan lapangan dilakukan meskipun demikian hal tersebut tidak dapat terjadi dengan sendirinya, melainkan harus diupayakan sejak awal proses dari tahapan persiapan, perencanaan dan pelaksanaan di mana di dalamnya ada tahapan monitoring dan evaluasi.

\section{Partisipasi Masyarakat dalam} Pelaksanaan Program Kota Tanpa Kumuh di Kelurahan Dadok Tunggul Hitam dan Kelurahan Alai Parak Kopi

Partisipasi dalam perencanaan program keikutserataan masyarakat dilihat dalam rapat-rapat. Sejauh mana masyarakat dilibatkan dalam proses perencanaan dan penyusunan serta penetapan program pembangunan dan sejauh mana masyarakat memberikan sumbangan pemikiran dalam bentuk saran untuk pembangunan. Partisipasi dalam pelaksanaan dilihat melalui wujud nyata masyarakat tersebut berupa: partisipasi dalam bentuk tenaga, partisipasi dalam bentuk uang, partisipasi dalam bentuk harta benda yang berguna bagi pelaksanaan pembangunan.

3. Kendala dalam Pelaksanaan Program Kota Tanpa Kumuh di Kelurahan Dadok Tunggul Hitam dan Kelurahan Alai Parak Kopi
Kendala yang dihadapi selama pelaksanaan tidak begitu serius hanya saja sebagian masyarakatnya tidak ikut serta dikarenakan kesibukan pekerjaan, dan masyarakat masih belum paham mengenai adanya program Kota Tanpa Kumuh ini, dimana mereka tidak menghadiri bentuk sosialisasi dari program ini.

\section{KESIMPULAN}

Pelaksanaan Program Kota Tanpa Kumuh di Kelurahan Dadok Tunggul Hitam dan Alai Parak Kopi dilakukan melalui tahap-tahap pelaksanaan suatu program yaitu Tahap Persiapan, Tahap Perencanaan, Tahap Pelaksanaan, dan Tahap Keberlanjutan. Setelah melalui ke empat tahap tersebut pelaksanaan program Kota Tanpa Kumuh di Dua Kelurahan tersebut berjalan lancar. Partisipasi masyarakat dalam pelaksanaan program Kota Tanpa Kumuh di Kel. Dadok Tunggul Hitam dan Kel. Alai Parak Kopi bisa dikatakan masih belum sempurna, karena masih ada masyarakat yang tidak terlibat dalam pelaksanaan dikarenakan kesibukan pekerjaan.

Partisipasi masyarakat dalam pelaksanaan harus ditingkatkan lagi, baik itu dari tahap persiapan, perencanaan, pelaksanaan dan keberlanjutan. Dan melalui program Kota Tanpa Kumuh diharapkan dapat menumbuhkan kekompakan dari setiap masyarakat dengan masyarakat, masyarakat dengan elemen kelurahan dan elemen Kota Tanpa Kumuh. 


\section{Daftar Pustaka}

Apriliana, Sahira. 2018. Partisipasi Masyarakat Dalam Pelaksanaan Program Kota Tanpa Kumuh (Kotaku). Balikpapan

Irvan, Hafidzita Eka Putri. 2018. Partisipasi Masyarakat Dalam Program Kota Tanpa Kumuh (Kotaku) Di Kelurahan Pesisir Kecamatan Lima puluh. Kota Pekanbaru

Kartini, Kartono. 1997. Metodologi Research Sosial. Alumni Bandung: Bandung

Moleong, Lexy J. 1991. Metodologi Penelitian Kualitatif. Remaja Rosdakarya: Bandung.

Pedoman Umum, KOTAKU (Kota Tanpa Kumuh), (Direktur Jendral Cipta Karya 2015)

Rohimat, Dadan dkk. 2017. Partisipasi Masyarakat Dalam Implementasi Program Kotaku /Pnpm Di Kecamatan Ciawi

Rukminto, Isbandi, Adi. 2008. Intervensi Komunitas, Pengembangan Pemberdayaan Masyarakat. PT. Raja Grafindo Persada: Jakarta
Sugiyono. 2012. Metode Penelitian Kuantitatif Dan Kualitatif Dan R\&D. Bandung: Alfabeta.

Tjokroamidjojo, Bintoro. 1980. Perencanaan Pembangunan. Jakarta: Gunung Agung.

Theresia, Aprillia dkk. 2014. Pembangunan Berbasis Masyarakat. Bandung: Alfabeta.

UU No 1 Tahun 2011 Tentang Perumahan dan Kawasan permukiman

SE Direktorat Cipta Karya No 40/SE/DC/2016

Http://Kotaku.pu.go.id:8081/wartad etil

Http:/ / prodeskel.binapemdes.kemen dagri.go.id

Https://padangkota.bps.go.id/ 